\title{
Participation of nurses in the execution of clinical research protocol about technological innovation
}

\author{
Participação do enfermeiro na execução de protocolo de \\ pesquisa clínica de inovação tecnológica \\ Participación del enfermero en la ejecución de protocolo de \\ investigación clínica de innovación tecnológica
}

Luciane Patrícia Andreani Cabral' ${ }^{1}$, Eduardo Mendonça Scheerenn ${ }^{1}$, Marcia Regina Cubas ${ }^{1}$ ${ }^{1}$ Pontifícia Universidade Católica do Paraná,
Programa de Pós-graduação em Tecnologia em
Saúde, Curitiba, PR, Brasil.

\begin{abstract}
Objective: To report the nurse's experience of inclusion in interdisciplinary clinical study about technological innovation, involving people with spinal cord injury. Method: Descriptive experience report. The empirical support was based on notes about perspectives and practice of clinical research, with a multi-professional nursing, physical education, physiotherapy and engineering staff. Result: The qualification includes the elaboration of the document for the Ethics Committee, familiarization among the members of staff and with the studied topic, and also an immersion into English. The nurse's knowledge gave support to the uptake of participants and time adequacy for data collection, preparation and assistance of the participants during the intervention and after collection. Nursing theories and processes have contributed to reveal risky diagnoses and the plan of care. It was the nurse's role to monitor the risk of overlapping methodological strictness to the human aspect. The skills for the clinical research must be the object of learning, including students in multidisciplinary researches. Conclusion: To qualify the nurse for clinical research and to potentialize its caregiver essence, some changes are needed in the educational system, professional behavior, attitude and educational assistance.
\end{abstract}

\section{DESCRIPTORS}

Nursing Research; Biomedical Research; Innovation; Technology.
Corresponding author:

Eduardo Mendonça Scheeren

Escola Politécnica, Programa de Pós-Graduação em Tecnologia em Saúde

Rua Imaculada Conceição, 1155. Curitiba -

Paraná.

CEP 80215-901 - Curitiba, PR, Brasil

eduardo.scheeren@pucpr.br 


\section{INTRODUCTION}

Brazilian nursing has excelled in political spaces of funding research organizations. The production of knowledge in the area, for being significant and specifically related to the Brazilian reality, is considered internationally competitive ${ }^{(1)}$. However, clinical research is still in its beginning in Brazilian nursing, i.e., there is a gap in the development of clinical trials for care practice, so that the Nursing science can predicate its actions on clinical evidence ${ }^{(2)}$. The literature on the subject states that the nurse contribute to different application areas of the results from clinical research and can assume functions in this issues, such as monitorship, collaboration, education and coordination ${ }^{(3)}$.

According to the methodological routine, the assistance to participants of clinical research, mostly, is made by only one care provider. However, clinical studies conducted by research groups require interaction between researchers from different areas of knowledge, with technical and scientific preparation related to their specific areas. Added to this complexity is the fact that certain participants, for their condition and vulnerability, need specific care in the various stages to which they are submitted ${ }^{(4)}$.

Being a devastating condition that has huge impact on a person's life ${ }^{(4)}$, spinal cord injuries are the focus of several researches. Clinical studies are performed for the diagnosis, treatment, rehabilitation and social integration process. In the area of rehabilitation, clinical studies seek to develop techniques and instruments which may promote care and recovery, involving different researchers in all stages, including nurses ${ }^{(5)}$.

The research that derived from this experience report is inserted in a universal interdisciplinary project in the field of Rehabilitation Engineering, which aims to build equipment resulting from the combination of functional electrical stimulation with an active orthosis, aiming to improve the performance of locomotion of people with Spinal Cord Injury (SCI).

To achieve this goal, a lot of research has been conducted to help in the decision-making process when constructing the equipment. During the development process of the project, a very important aspect is to investigate the reaction of a person's muscle with SCI to electrical stimulation. Studies ${ }^{(6-7)}$ concluded by the group showed the best parameters for electrical stimulation in relation to occurrence of muscular fatigue; systems for the measurement of muscle fatigue level; and electrical stimulation for closedloop applications.

The participation of the nurse was limited to the unfoldment of the universal project, which aimed to measure the time between the beginning of electrical stimulation and the first muscle fasciculation and the beginning of the response, called electromechanical delay in the literature. Preliminary results indicate differences in the nerve conduction velocity of healthy people with spinal cord injury, inferring strategies of the computational control system of activation and inhibition of the musculatures involved in the walking process of a person with spinal cord injury.

Considering this an unexplored field in nursing, this article aims to report the experience of including nurses in an interdisciplinary clinical study about technological innovation, involving people with spinal cord injury.

The relevance of this report is that it contributes to the base of knowledge that underlies the practice of nurses, to cooperate with the multidisciplinary team in a scientific way, with their professional area related to good clinical practices.

\section{METHOD}

This is a descriptive study, an experience report, that used as empirical base notes on guidance and practice of clinical research developed in the context of a master's degree, in the period from 2012 to 2014 . A female nurse participated in part of the systematic process of development of a clinical research, which involved a staff of nursing, physical education, physiotherapy and engineering professionals. The location of interventions was a rehabilitation institution in the city of Curitiba, Paraná. The universal project was approved by the Research Ethics Committee (REC) of Pontifícia Universidade Católica do Paraná (PUCPR), under protocol No. 400,141, from 2013.

The results and discussion were organized according to the nurse's participation in the stages of research: qualification period; elaboration of the document for REC; qualification of the research participants and application of the questionnaire for the initial data collection (identification and health conditions); preparation of participants for data collection; follow-up of participants during the intervention and after data collection; operationalization of technological instruments, and analysis of results.

\section{RESULTS}

Although it is a continuous process, the focus of initial qualification lasted for 12 months, with activities that respected a hierarchical order for the execution of the research stages. Readings were performed for the exploration of the research topic, in a specific and comprehensive way - books, forums of experts and articles written by the research group or others.

Concomitantly to the qualification process, the project was prepared to receive ethics approval and for the followup of practical research activities carried out by the research group. At this stage, we had the beginning of small participations in the methodological procedures of clinical trials, with the approval and supervision of the responsible for the research, which contributed to the familiarization with the staff and procedures, as well as to the operationalization of technological instruments.

The nurse participated in the process of uptaking 24 participants for the clinical research. Based on the criteria of inclusion established, the participants were welcomed by the female nurse who explained the type of participation in the research and introduced the Informed Consent Term. After the consent, she applied the questionnaire about identification and health conditions, and carried out procedures for the preparation of data collection, monitoring the intervention and after data collection procedure. This process lasted two months. 
For the analysis of results related to the research stage for which she was responsible, the nurse learned how to use MatLab software, which gave support to the process of mathematical analysis of the collected biological signals.

\section{DISCUSSION}

Researchers who are engaged in clinical research say that, although there is no consensus about the definition and documentation of the role of nurses in clinical studies - whether as scientists or main researchers -, there are efforts aiming at these issues. They also add that nurses who provide health care or coordinate studies can, according to their expertise, improve the efficiency of investigation, safety of participants and quality of data ${ }^{(8,9)}$. This was observed in our research.

To ensure the active participation of any member of a research team conducting a clinical research in all stages of its process, it is necessary a period of qualification, whether for familiarization with research tools or protocols. This initial process is important to give reliability to results, avoiding, as much as possible, mistakes related to the use of equipment and/or research procedures. During qualification some doubts related to the readings have arisen, emphasizing the importance of meetings with the advisor and with the research group for discussion and clarification.

This experience enabled the dialogue between different researchers, which influences the judgment in processes of research, helping in the researcher formation, and the development of leadership in clinical research groups. These aspects were considered relevant for the insertion of nursing professionals in institutional activities related to graduate programs ${ }^{(1)}$.

The basic contents of technological areas (engineering), not available in the curriculum of the profession, were given in research courses. However, the inclusion of nurses in a specific technological research requires an enhancement for the acquisition of new knowledge.

An important aspect is the urgency of the reading of texts in English. A study performed in Spanish universities indicates the need of including contents in English in the curriculum of undergraduate programs to adapt the profile of professional skills to global systems and consolidate a society without language barriers ${ }^{(10)}$. This is far from reality, but must receive more attention so nurses can dedicate themselves to researches of greater impact.

An important stage in the formation of clinical researchers is the preparation of the document that must be submitted to REC, since this type of research deals, inevitably, with irreversible interventions and, in the case reported, with a vulnerable population. Nurse demonstrate their knowledge to anticipate risk situations and include in the project, in detail, the care needed to assure the assistance to participants in all phases of the research to which they are associated with ${ }^{(8)}$. In their academic background, the content offered to nurses about nursing theories that give support to care focused on human needs (as the one proposed by Horta), and the application of the nursing process can contribute to risk analysis and to plan specific health care.
The preparation of the document for REC needs a researcher with improved skills, which are developed during their basic training and with the addition of others provided by interdisciplinary knowledge, e.g., aspects related to the description of methods for technological innovation. An example of the contribution of specific nursing knowledge was observed in the elaboration of a schedule for data collection. To a researcher not used to deal with human care issues, a time of 30 minutes, per participant, would be appropriate for the application of the clinical trial and to collect necessary data.

On the other hand, the nurses found stipulating times would be necessary to ensure clinical conditions (vital signs before and after collection) and basic care needs related to physical mobility (transportation), comfort (change of clothes), disposal (change of urinary catheter and intestinal stimulation), health education (anamnesis and explanation of procedures), cutaneous-mucous integrity (skin preparation for electrode placement), gregarious (family participation), emotional security (anxiety caused by the collection) and bond (reception).

Being a vulnerable group whose exposure could happen from their selection to the after-data-collection period, special care should be provided to the environment in which the research will be conducted, ensuring privacy and comfort. The nurse has background to analyze the space and, if necessary, make adjustments.

Due to methodological strictness of the procedures, during the follow-up process of the volunteers there is a risk that the human aspect may be overwhelmed by such strictness, and the nurse must be careful and observe this environment.

In this research, although medical care was ensured in dealing with possible damage caused by the intervention, a situation occurred and the nurse was attentive and had an important and specific role in the case. One of the volunteers, after collection, reported an edema in the knee joint. Before the exclusive application of the ethical protocol, the nurse and physical therapist responsible for the intervention made a home visit to give support to the volunteer, analyze the situation and perform the assistance based on integrality.

A survey - that assessed the most frequent and important activities carried out by nurses in a clinical research center - indicated the dimension of clinical practice as the most frequent and important one. Among the activities of this dimension, the most important was predicting adverse events, monitoring and planning of actions of direct care to the event ${ }^{(9)}$, which corroborates with the actions developed in this report.

Aspects related to the skills required to the operationalization of technological instruments and to the analysis of results of clinical research lead to discuss if the specific knowledge of this new field should be part of learning during undergraduate or specialization programs, which could include students in multidisciplinary research whether through final examinations or scientific initiation projects. This situation was reported also by a study that has described insertion, difficulties and strategies adopted by nurses in clinical research ${ }^{(3)}$. 
The experience reported regards a different universe of exclusive practical assistance, involving an experience of overcoming personal and theoretical limits, thus referring to gaps in the nurse formation to perform practice clinical research activities.

Added to these gaps we have the altruism related to this profession that is often undervalued in its activities and skills. However, altruism was identified as part of the identity of research coordinators, and this is relevant to make volunteers aware of the importance of their participation in clinical research; to minimize conflicts between research and care and to disprove the undervaluing of the coordinator's role ${ }^{(11)}$.

Limitations of the nurse in clinical research were partially overcome by recommendations and incentives of the advisor, so the apprentice could have a distinguished perspective vision in relation to other staff members, that is, the nurse's perspective and how they could significantly contribute to the research.
The limitation of this study is on a fine line - common in experience reports - that exists between the description based on the method and emotional issues related to the overcoming of personal boundaries, which requires a critical self-analysis regarding researches.

\section{CONCLUSION}

The participation of nurses in clinical research gives support for a better understanding of the profession and helps in the transfer of experiences and knowledge.

There is a need for changes in professional behavior, attitude and educational support, and changes in educational systems to qualify nurses in the field of clinical research, potentializing their knowledge and the essence of a caregiver.

The critical knowledge resulting from the participation in the full process of a clinical research supports professional advancements and provides an articulated scientific contribution to various areas of knowledge.

\section{RESUMO}

Objetivo: Relatar a experiência de inclusão do enfermeiro em estudo clínico interdisciplinar de inovação tecnológica, envolvendo pessoas com lesão medular. Método: Relato de experiência descritivo. As bases empíricas foram anotações de orientações e prática de pesquisa clínica, com equipe multiprofissional da enfermagem, educação física, fisioterapia e engenharias. Resultado: A capacitação incluiu a elaboração do documento para Comitê de Ética, familiarização com equipe e tema de estudo e imersão em língua inglesa. O conhecimento do enfermeiro ancorou a captação de participantes e adequação temporal da coleta de dados, preparação e acompanhamento dos participantes durante a intervenção e pós-coleta. As teorias e o processo de enfermagem contribuíram para evidenciar diagnósticos de risco e no planejamento de cuidados. Foi papel do enfermeiro a vigilância do risco de sobreposição do rigor metodológico ao caráter humano. As habilidades para a pesquisa clínica deverão ser objeto de aprendizagem incluindo estudantes em pesquisas multidisciplinares. Conclusão: Para qualificar o enfermeiro para pesquisa clínica e potencializar sua essência de cuidador são necessárias mudanças nos sistemas de ensino, comportamento profissional, atitude e suporte educacional.

\section{DESCRITORES}

Pesquisa em Enfermagem; Pesquisa Biomédica; Inovação; Tecnologia.

\section{RESUMEN}

Objetivo: Relatar la experiencia de inclusión del enfermero en estudio clínico interdisciplinario de innovación tecnológica, involucrando a personas con lesión medular. Método: Relato de experiencia descriptivo. Las bases empíricas fueron apuntes de orientaciones y práctica de investigación clínica, con equipo multiprofesional de enfermería, educación física, fisioterapia e ingenierías. Resultado: La capacitación incluyó la elaboración del documento para el Comité de Ética, la familiarización con el equipo y el tema de estudio e inmersión en lengua inglesa. El conocimiento del enfermero ancló la captación de participantes y la adecuación temporal de la recolección de datos, preparación y seguimiento de los participantes durante la intervención y post recolección. Las teorías y el proceso de enfermería contribuyeron a evidenciar diagnósticos de riesgo y la planificación de cuidados. Fue papel del enfermero la vigilancia del riesgo de superposición del rigor metodológico al carácter humano. Las habilidades para la investigación clínica deberán ser objeto de aprendizaje incluyéndose a estudiantes en investigaciones multidisciplinarias. Conclusión: A fin de cualificar al enfermero para la investigación clínica y potenciar su esencia de cuidados son necesarios cambios en los sistemas de enseñanza, comportamiento profesional, actitud y soporte educativo.

\section{DESCRIPTORES}

Investigación en Enfermería; Investigación Biomédica; Innovación; Tecnología.

\section{REFERENCES}

1. Erdmann AL, Pagliuca LMF. O conhecimento em enfermagem: da representação de área ao Comitê Assessor de Enfermagem no CNPq. Rev Bras Enferm. 2013;66(n.esp.):51-9.

2. Bastos MLA. Experimental basic research in nursing [editorial]. J Nurs UFPE On Line [Internete]. 2013 [cited 2014 Aug 12];7(3). Available from: http://www.revista.ufpe.br/revistaenfermagem/index.php/revista/article/view/4663/pdf_2062

3. Aguiar DF, Camacho KG. The daily activity of the nurse in clinical research: an experience report. Rev Esc Enferm USP. 2010;44(2):526-30.

4. Bryceland C, Ellis S, Beaumont D, Shakur H, Coats TJ. Good clinical practice in trauma care research: considerations for inter-hospital patient transfers. Int Emerg Nurs. 2015;23(1):42-4. 
5. Arone EM, Cunha ICKO. Avaliação tecnológica como competência do enfermeiro: reflexões e pressupostos no cenário da ciência e tecnologia. Rev Bras Enferm. 2006;59(4):569-72.

6. Krueger E, Scheeren EM, Nogueira-Neto GN, Neves EB, Button VLSN, Nohama P. Analysis of functional electrical stimulation parameters by muscular contraction time and knee joint angular variation. Biomed Eng Lett. 2013;3(1):1-7.

7. Krueger E, Scheeren EM, Nogueira-Neto GN, Neves EB, Button VLSN, Nohama P. Relationship between peak and mean amplitudes of the stimulating output voltage for functional control of the knee by spinal cord patients and healthy volunteers. Rev Bras Eng Bioméd. 2013;29(2):144-52.

8. Hastings CE, Fisher CA, McCabe MA, Consortium NCRN. Clinical research nursing: a critical resource in the national research enterprise. Nurs Outlook. 2012;60(3):149-56.

9. Bevans M, Hastings C, Wehrlen L, Cusack G, Matlock AM, Miller-Davis C, et al. Defining clinical research nursing practice: results of a role delineation study. Clin Transl Sci. 2011;4(6):421-7.

10. Camacho-Bejarano R, Barquero-González A, Mariscal-Crespo MI, Merino-Navarro D. English in the nursing degree: a pending subject. Rev Lat Am Enfermagem. 2013;21(2):641-8.

11. Fisher JA, Kalbaugh CA. Altruism in clinical research: coordinators' orientation to their professional roles. Nurs Outlook. 2012;60(3):1438. e1. 